\title{
2 方向水平地動を受ける構造物の電算機-試験機オンライン応答解析
}

2 方向水平地動を受ける $\mathrm{H}$ 形鋼柱の弾塑性応答性状（II）

$\begin{array}{lllll}\text { 正会員 } & \text { 谷 } & 口 & \text { 英 } & \text { 武* } \\ \text { 正会員 } & \text { 高 } & \text { 梨 } & \text { 晃 } & \text { - ** } \\ \text { 正会員 } & \text { 田 } & \text { 中 } & & \text { 尚*** }\end{array}$

\section{1. 序}

2 方向あるいは任意方向の地動に対する構造物の応答 挙動を数值解析によりシミュレートするため種々の解析 モデルが用いられている。鋼素材の応力ーひずみ関係を 数式モデル化し，部材を微小要素に分割して釣合式を数

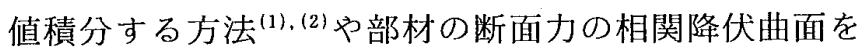
仮定し塑性理論を応用した復元力特性のモデル化の方

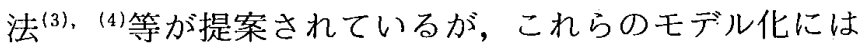
多くの仮定が含まれており，現実の現象之の対応が十分 に検討されていない。

筆者らは, 構造物の地震応答解析を行う際に復元力特 性のモデル化を一切行わずに, 計算システムの中に構造 物, あるいはその一部の部材の加力実験を組み込み, 計 算機により実験を制御し，刻々変化する復元力をその都 度計算の中にとり込んで構造物の応答を計算する電算機 一試験機オンラインシステムを開発し(5)，同システムを 用いて種々の鋼構造物の地震応答解析を行っている。

同システムを 2 自由度系の応答解析に適用した例とし ては, 高梨らによる 2 層 1 スパン鉄骨骨組の地震応答解 析 $^{(6)}$, 岡田らによる 2 方向地震入力をうける RC 構造物の地震応答解析が行われている(7)。

本報では，電算機-試験機オンラインシステム を利用して地震波の水平 2 方向成分を断面 2 主軸 方向に同時に作用させた時, 柱の崩壊過程をシ ミュレートする方法を示す。次に，この方法を鋼 板から集成した $\mathrm{H}$ 形断面柱の模型試験体に適用 した結果を示し， 2 方向水平地動をうける $\mathrm{H}$ 形 鋼柱の弾塑性挙動を検討する。さらに, $\mathrm{H}$ 形鋼 柱を線素に分割し，各線素の伸縮を解析すること によって応答性状を求める方法を示し，さきの才， ンライン応答実験の結果とこの数值解析法の結果

*大林組・工博

** 東京大学生産技術研究所 教授・工博

*** 東京大学生産技術研究所 教授・工博 (昭和 57 年 10 月 29 日原稿受理日，討論期限昭和 58 年 7 月末日）

\section{とを比較検討する。}

\section{2. 電算機-試験機オンライン応答解析}

電算機-試験機オンラインシステムを 2 自由度系に適 用する方法については文献 (6) で詳しく検討されてい るが，本報でも同様の方法によっている。以下に，2 方

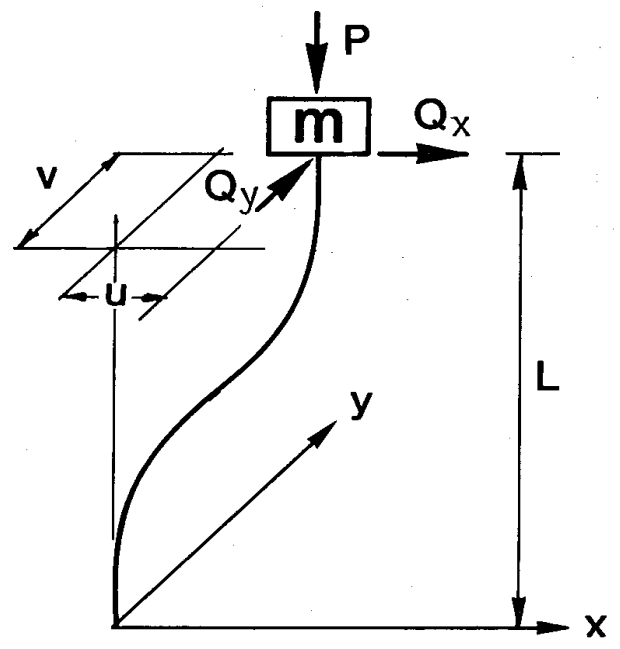

Fig. 2-1 A Iumped mass model

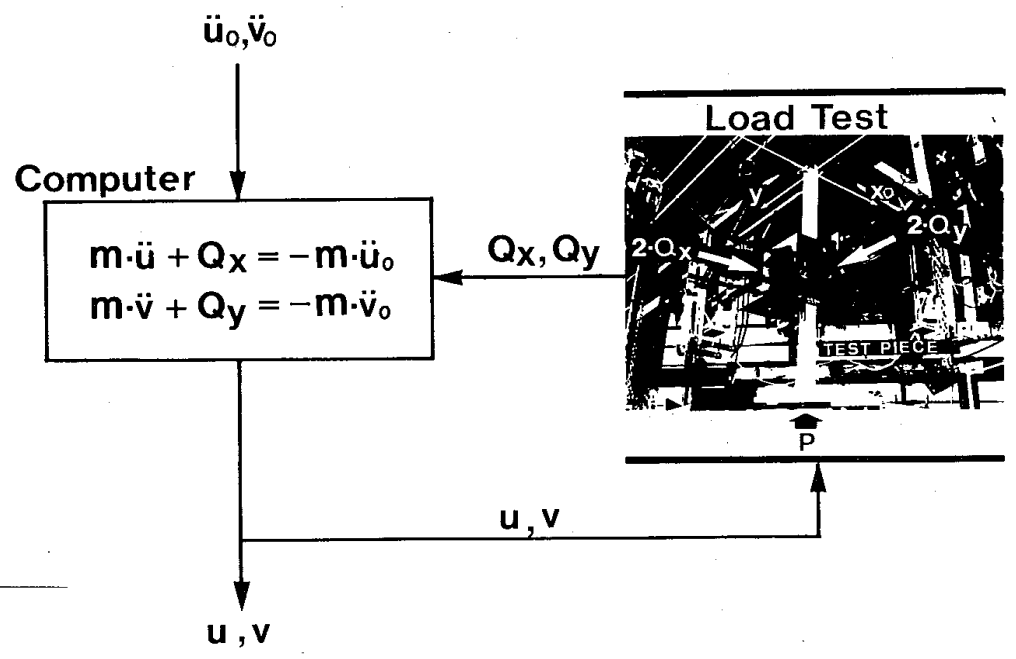

Fig. 2-2 Block diagram of Computer-Actuator on-line simulation 
向地震入力をうける骨組の地震志答解析に同システムを 利用する際の概要を説明する。

\section{2-1 解析モデル上解析方法}

整形な平面を持ち，剛な床と等断面の柱から構成され ている 1 層立体骨組を想定する。このような骨組の応答 性状は 1 本の柱の弾塑性忘答性状を調べることにより大 略把握できるから，Fig. 2-1 に示すような 1 質点系振 動モデルを想定し，Fig. 2-2に示すように1本の柱の 加力実験を応答計算に組み込み， 2 方向地震入力をうけ る骨組の応答シミュレーションを行う。

質量 $m$ は柱頭に集中しているものとし，㧪れ震動， 粘性減衰を無視すると振動方程式は次式となる。

$$
\begin{aligned}
& m \cdot \ddot{u}^{i}+Q_{x}{ }^{i}=-m \cdot \ddot{u}_{0}{ }^{i} \\
& m \cdot \ddot{v}^{i}+Q_{y}{ }^{i}=-m \cdot \ddot{v}_{0}{ }^{i}
\end{aligned}
$$

ここで $m:$ 質量

$\ddot{u}^{i}: x$ 方向（柱弱軸

曲げ方向）の応

答加速度

$\ddot{v}^{i}: y$ 方向（柱強軸

曲げ方向）の応

答加速度

$Q_{x^{i}}{ }^{i} x$ 方向（柱弱軸

曲げ方向）の

復元力

$Q_{y}{ }^{i}: y$ 方向（柱強軸 曲げ方向）の復 元力

$\ddot{u}_{0}{ }^{i}: x$ 方向（柱弱軸 曲げ方向）の 地動の加速度

$\ddot{v}_{0}{ }^{i}: y$ 方向（柱強軸 曲げ方向）の 地動の加速度

なお，添字 $i$ は， step by step の応答計 算において，時間刻み $\Delta t$ としたときの時 刻 $t=i \cdot \Delta t$ における值であることを示し ている。

応答加速度 $\ddot{u}_{i}, \ddot{v}_{i}$ は, 中央差分法によ り次式のように変位で近似的に表現でき る。

$$
\begin{array}{ll}
\ddot{u}^{i}=\left(u^{i+1}-2 \cdot u^{i}+u^{i-1}\right) /(\Delta t)^{2} & (2-2-\mathrm{a}) \\
\ddot{v}^{i}=\left(v^{i+1}-2 \cdot v^{i}+v^{i-1}\right) /(\Delta t)^{2} & (2-2-\mathrm{b})
\end{array}
$$

オンライン応答解析が $i$ ステップ $(t$ $=\Delta t \cdot i)$ まで終了したとすると，次ステッ プ $(t=\Delta t \cdot(i+1))$ の応答変位 $u^{i+1}, v^{i+1}$ は, 既知の変位 $u^{i}, u^{i-1}, v^{i}, v^{i-1}$, 入力デ一 夕である地動の加速度 $\ddot{u}_{0}{ }^{i}, \ddot{v}_{0}{ }^{i}$, それに $t=\Delta t \cdot i$ における復元力 $Q_{x}{ }^{i}, Q_{y}{ }^{i}$ が求ま
れば，(2-1) 式，(2-2) 式の各式から計算することがで きる。Fig. 2-2 に示すようにオンライン応答解析では, 復元力 $Q_{x}{ }^{i}, Q_{y}{ }^{i}$ を解析と並行して行われる柱の載荷実 験から測定して求めている。このようにして求められる 次ステップの応答変位 $u^{i+1}, v^{i+1}$ が変位制御により正確 に柱試験体に加えられる。次ステップ以後の忍答は，同 様の手順を繰り返すことにより求められる。中央差分法 による振動方程式の数值積分における微小な時間刻み $\Delta t$ は，本解析では 0.01 秒である ${ }^{(6)}$ 。

なお，中央差分法による振動方程式の解法では，応答 変位が小さい場合の復元力の測定誤差による影響を小さ くするために，実験開始からいずれかの水平変位が 2 $\mathrm{mm}$ を越えるまで（弾性範囲内）は，本実験に先だち弾

\begin{tabular}{|c|c|c|c|c|c|c|c|c|c|c|}
\hline SPECIMEN & $\begin{array}{c}\mathrm{H} \\
(\mathrm{cm})\end{array}$ & $\begin{array}{c}B \\
(\mathrm{~cm})\end{array}$ & $\begin{array}{c}t w \\
(\mathrm{~cm})\end{array}$ & $\begin{array}{c}t f \\
(\mathrm{~cm})\end{array}$ & $\begin{array}{l}\mathrm{L} \\
(\mathrm{cm})\end{array}$ & $\begin{array}{c}A \\
\left(\mathrm{~cm}^{2}\right)\end{array}$ & $\begin{array}{l}\mathrm{Ix} \\
\left(\mathrm{cm}^{4}\right)\end{array}$ & $\begin{array}{l}\mathrm{Iy} \\
\left(\mathrm{cm}^{4}\right)\end{array}$ & $\begin{array}{r}M p c x \\
(t \quad c m)\end{array}$ & $\begin{array}{r}M \text { poy } \\
(t \quad \mathrm{~cm})\end{array}$ \\
\hline$D B C-A-1$ & 6.95 & 7.00 & 0.644 & 0.631 & 88.79 & 12.5 & 98.4 & 36.2 & 90.9 & 51.7 \\
\hline$A-2$ & 6.94 & 7.00 & 0.637 & 0.626 & 88.90 & 12.4 & 97.3 & 35.9 & 90.4 & 50.8 \\
\hline$A-3$ & 6.95 & 7.00 & 0.644 & 0.631 & 88.84 & 12.5 & 98.3 & 36.2 & 91.2 & 51.2 \\
\hline$A-4$ & 6.94 & 7.00 & 0.638 & 0.627 & 88.98 & 12.4 & 97.5 & 35.9 & 90.5 & 50.9 \\
\hline$A-5$ & 6.95 & 7.00 & 0.640 & 0.622 & 88.84 & 12.4 & 97.5 & 35.7 & 90.5 & 50.6 \\
\hline$D B C=B-1$ & 6.97 & 7.00 & 0.645 & 0.627 & 88.93 & 12.4 & 96.8 & 36.0 & 90.3 & 51.0 \\
\hline B -2 & 6.95 & 6.98 & 0.644 & 0.626 & 89.00 & 12.4 & 97.6 & 35.6 & 90.7 & 50.6 \\
\hline $\mathrm{DBC}-\mathrm{C}-1$ & 6.96 & 6.99 & 0.645 & 0.629 & 88.94 & 12.5 & 98.5 & 35.9 & 91.3 & 51.0 \\
\hline$c-2$ & 6.95 & 7.01 & 0.643 & 0.633 & 89.04 & 12.5 & 98.7 & 36.4 & 91.5 & 51.5 \\
\hline$c-3$ & 6.95 & 7.00 & 0.642 & 0.632 & 88.61 & 12.5 & 98.5 & 36.3 & 91.4 & 51.4 \\
\hline$C-4$ & 6.94 & 6.96 & 0.645 & 0.660 & 89.00 & 12.8 & 100.2 & 36.3 & 93.0 & 52.9 \\
\hline
\end{tabular}
性範囲内で静的加力実験を行って測定した岡性を用いて 計算機内で線形加速度法による応答計算を行っている。

Table 2-1 Measured values of specimens

H:Height B:Width of Flange tw:Thickness of Web tf:Thickness of Flange $L$ : Length A:Area Ix(Iy):Moment of Inertia

Mpcx(Mpcy):Plastic moment under axial load

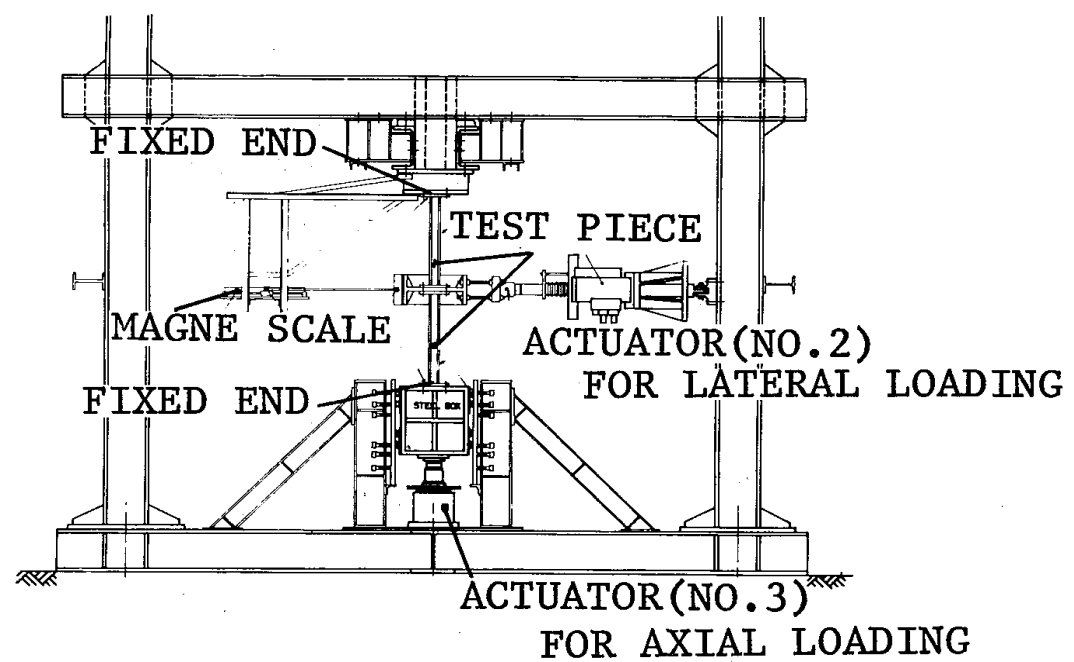

Fig. 2-3 The overall loading system 
もちろん，この場合も各ステップごとの応答変位は正確 に柱試験体に加えられる。

2-2 オンライン応答奉験

\section{i ) 試験体}

オンライン応答解析と並行して行う柱の載荷実験に用 いられる試験体は, SS 41 材の $6 \mathrm{~mm}$ 厚の鋼板をすみ肉 溶接により組み立てて製作した $H_{B}-70 \times 70 \times 6 \times 6$ で, 強軸まわりの細長比 $\lambda_{x}=32$, 弱軸まわりの細長比 $\lambda_{y}=53$ である, 試験体の製作に使用した鋼材の降伏応 力度は引張試験によると $\sigma_{r}=3.30 \mathrm{t} / \mathrm{cm}^{2}$ であった。実 測による試験体の形状寸法, 断面諸量を Table 2-1 に示 す。なお，試験体には焼鈍等の特別な後処理は施されて いない。

\section{ii）実験装置}

オンライン応答実験に用いる載荷装置は, Fig. 2-3 に示すように加力用鉄骨フレームと 3 台の電気油圧式ア クチュエータにより構成されている。試験体は，中央に 水平力加力用治具をはさんで 2 本 1 組として使用する。 上側の試験体上端は加力用鉄骨フレームに高力ボルトに より固定，下側の試験体の下端は試験体材軸方向変位の み追従可能な治具に固定され，この治具を介して定軸力 を加える。実験と並行して行われる応答解析により得ら れる各ステップごとの 2 方向水平変位は, Fig. 2-2 に 示すように水平面内に直交して配置された 2 台の電気油 圧式アクチュエータにより試験体中央に加えられる。2 体 1 組の試験体のうち 1 体の変形状態が Fig. 2-1 の振 動モデルの柱のそれに相当する。なお，加えられる定軸 力の大きさは, 前報の繰返し載荷実験と同じで柱降伏軸 力 $P_{Y}$ の $30 \%\left(P_{Y}=A \cdot \sigma_{Y}, A\right.$ : 断面積, $\sigma_{Y}$ : 降伏応力 $)$ であり，荷重制御して載荷される。

\section{2-3 入力地震波之解析のための諸定数}

解析に用いる地震波形として, 1968 年十勝沖地震の
八戸における記録波のうち最大加速度付近 8 秒間(以下， HACHINOHE と略す) と, 1940 年 El Centro 地震の 記録波のう去最大加速度付近 10 秒間（以下，EL CENTRO 上略す）を用いる。Fig. 2-4 に使用した地震 波の加速度の時刻歴を示す。断面主軸の方向と入力地震

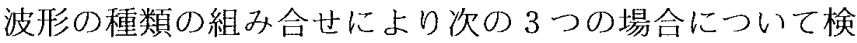
討する。

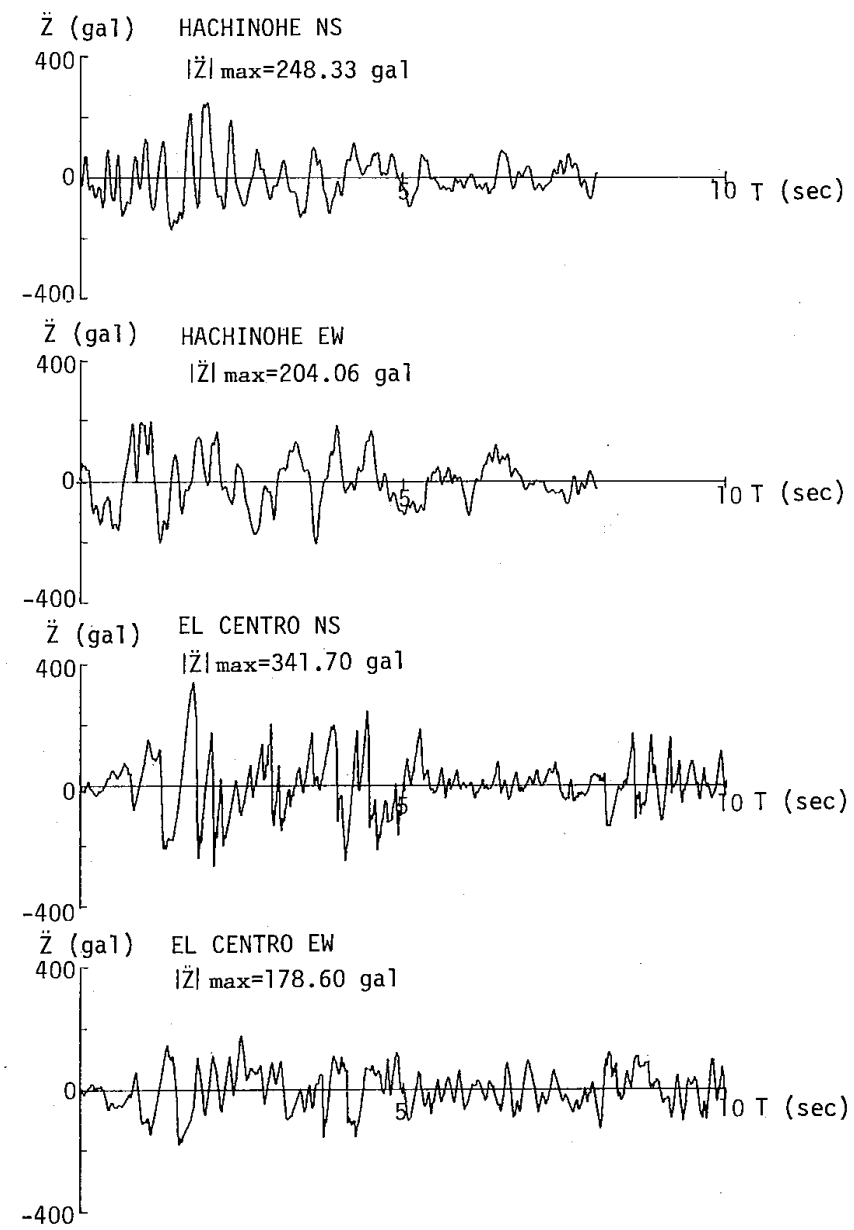

Fig. 2-4 Recorded ground accelerations
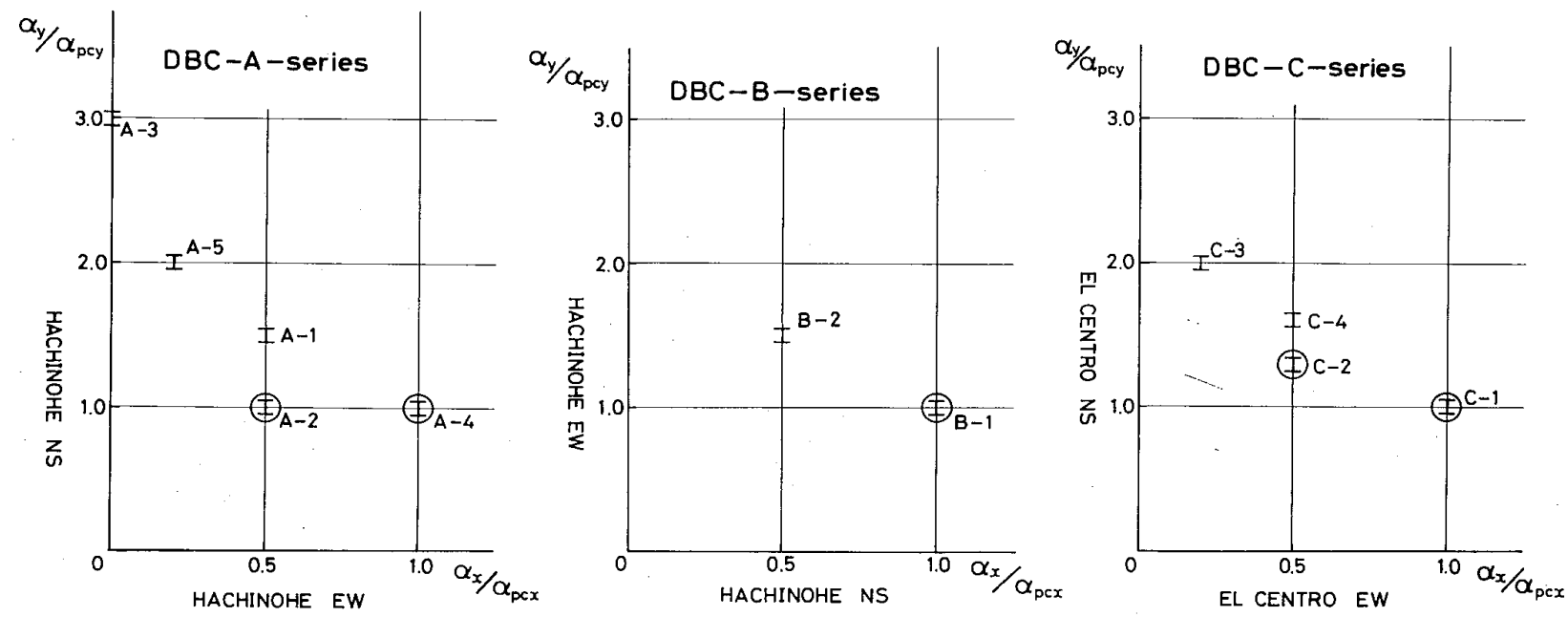

Fig. 2-5 The combinations of the intensities of ground accelerations 


\begin{tabular}{|c|c|c|c|c|c|c|c|c|}
\hline \multirow[b]{2}{*}{ SPECIMEN } & \multirow[b]{2}{*}{$\begin{array}{l}\text { DIREC- } \\
\text { TION }\end{array}$} & \multicolumn{4}{|c|}{ STRUCTURE } & \multicolumn{3}{|c|}{ GROUND MOTION } \\
\hline & & $\begin{array}{r}Q p c \\
(t)\end{array}$ & $\begin{array}{c}K e \\
(t / c m)\end{array}$ & $\begin{array}{c}T \\
(\sec )\end{array}$ & $\begin{array}{c}\mathrm{m} \\
\left(\mathrm{t} \cdot \sec ^{2} / \mathrm{cm}\right)\end{array}$ & $\alpha / \alpha p c$ & $\underset{(g a l)}{a}$ & $\begin{array}{l}\text { INPUT } \\
\text { EARTHQUAKE }\end{array}$ \\
\hline$D B C-A-1$ & $\begin{array}{l}x \\
y\end{array}$ & $\begin{array}{l}1.15 \\
2.05\end{array}$ & $\begin{array}{l}1.10 \\
2.85\end{array}$ & $\begin{array}{l}0.807 \\
0.5\end{array}$ & 0.0781 & $\begin{array}{l}0.5 \\
1.5\end{array}$ & $\begin{array}{r}31.9 \\
170.0\end{array}$ & $\begin{array}{r}\text { HACHINOHE-EW } \\
\text {-NS }\end{array}$ \\
\hline$A-2$ & $\begin{array}{l}x \\
y\end{array}$ & $\begin{array}{l}1.15 \\
2.04\end{array}$ & $\begin{array}{l}1.09 \\
2.86\end{array}$ & $\begin{array}{l}0.809 \\
0.5\end{array}$ & 0.0181 & $\begin{array}{l}0.5 \\
1.0\end{array}$ & $\begin{array}{r}31.6 \\
112.5\end{array}$ & \\
\hline$A-3$ & $\begin{array}{l}x \\
y\end{array}$ & $\begin{array}{l}1.16 \\
2.06\end{array}$ & $\begin{array}{l}3.12 \\
2.82\end{array}$ & $\begin{array}{l}0.793 \\
0.5\end{array}$ & 0.0183 & $\begin{array}{l}0.0 \\
3.0\end{array}$ & $\begin{array}{r}0.0 \\
345.9\end{array}$ & \\
\hline$A-4$ & $\begin{array}{l}x \\
y\end{array}$ & $\begin{array}{l}1.15 \\
2.04\end{array}$ & $\begin{array}{l}1.11 \\
2.93\end{array}$ & $\begin{array}{l}0.813 \\
0.5\end{array}$ & 0.0186 & $\begin{array}{l}1.0 \\
1.0\end{array}$ & $\begin{array}{r}61.6 \\
109.7\end{array}$ & \\
\hline$A-5$ & $\begin{array}{l}x \\
y\end{array}$ & $\begin{array}{l}1.14 \\
2.04\end{array}$ & $\begin{array}{l}1.12 \\
2.90\end{array}$ & $\begin{array}{l}0.806 \\
0.5\end{array}$ & 0.0184 & $\begin{array}{l}0.2 \\
2.0\end{array}$ & $\begin{array}{r}12.4 \\
222.2\end{array}$ & \\
\hline$D B C-B-1$ & $\begin{array}{l}x \\
y\end{array}$ & $\begin{array}{l}1.15 \\
2.03\end{array}$ & $\begin{array}{l}1.11 \\
2.82\end{array}$ & $\begin{array}{l}0.798 \\
0.5\end{array}$ & 0.0179 & $\begin{array}{l}1.0 \\
1.0\end{array}$ & $\begin{array}{r}63.3 \\
113.9\end{array}$ & $\begin{array}{r}\text { HACHINOHE-NS } \\
-E W\end{array}$ \\
\hline B-2 & $\begin{array}{l}x \\
y\end{array}$ & $\begin{array}{l}1.14 \\
2.04\end{array}$ & $\begin{array}{l}1.09 \\
2.84\end{array}$ & $\begin{array}{l}0.808 \\
0.5\end{array}$ & 0.0180 & $\begin{array}{l}0.5 \\
1.5\end{array}$ & $\begin{array}{r}31.6 \\
169.9\end{array}$ & \\
\hline $\mathrm{DBC}-\mathrm{C}-1$ & $\begin{array}{l}x \\
y\end{array}$ & $\begin{array}{l}1.15 \\
2.06\end{array}$ & $\begin{array}{l}1.11 \\
2.88\end{array}$ & $\begin{array}{l}0.806 \\
0.5\end{array}$ & 0.0182 & $\begin{array}{l}1.0 \\
1.0\end{array}$ & $\begin{array}{r}63.0 \\
112.8\end{array}$ & $\begin{array}{r}\text { EL CENTRO-EW } \\
-N S\end{array}$ \\
\hline$C-2$ & $\begin{array}{l}x \\
y\end{array}$ & $\begin{array}{l}1.16 \\
2.06\end{array}$ & $\begin{array}{l}1.11 \\
2.89\end{array}$ & $\begin{array}{l}0.807 \\
0.5\end{array}$ & 0.0183 & $\begin{array}{l}0.5 \\
1.3\end{array}$ & $\begin{array}{r}31.6 \\
146.1\end{array}$ & \\
\hline$C-3$ & $\begin{array}{l}x \\
y\end{array}$ & $\begin{array}{l}1.16 \\
2.06\end{array}$ & $\begin{array}{l}1.12 \\
2.93\end{array}$ & $\begin{array}{l}0.808 \\
0.5\end{array}$ & 0.0186 & $\begin{array}{l}0.2 \\
2.0\end{array}$ & $\begin{array}{r}12.5 \\
222.4\end{array}$ & \\
\hline$C-4$ & $\begin{array}{l}x \\
y\end{array}$ & $\begin{array}{l}1.19 \\
2.09\end{array}$ & $\begin{array}{l}1.13 \\
2.86\end{array}$ & $\begin{array}{l}0.795 \\
0.5\end{array}$ & 0.0181 & $\begin{array}{l}0.5 \\
1.6\end{array}$ & $\begin{array}{r}32.8 \\
184.9\end{array}$ & \\
\hline
\end{tabular}

$Q p c=M p c /(L / 2)$

Ke :Elastic stiffness

$\mathrm{m}$ :mass

$T=2 \pi \sqrt{M / K e}$
Table 2-2 The frame models analyzed and the input ground motions

示す。図中○印を付した骨組は， オンライン応答解析の結果, 応 答変位が発散せず，比較的安定 していた骨組を示す。

解析骨組として柱強軸曲げ方 向の弾性固有周期が 0.5 秒の骨 組を想定する。オンライン実験 に先だち, 各断面主軸方向に弾 性範囲内で静的に加力し; 各断 面主軸方向の弾性剛性 $K_{e x}$, $K_{e y}$ を測定する。柱強軸曲げ方 向の測定剛性 $K_{e y}$ を用いて想定 質量 $m \quad\left(=K_{e y} \cdot T_{y}{ }^{2} / 4 \pi^{2}, \quad T_{y}\right.$ : 柱強軸曲げ方向の弾性固有周 期）を定好。Table 2-2 に各 解析骨組の諸量, 入力地震波を 示す。

3. オンライン応答解析結果 オンライン応答解析の結果の 一部亡して, DBC-A-1, DBC - A-2, DBC-A - 4 の結果を

Fig. 3-1 - 3に示す。各 (a)

DBC-A シリーズ：柱弱軸曲げ方向に HACHINOHE $\mathrm{EW}$ 波, 強軸曲げ方向にHACHINOHE NS 波を入力。 柱試験体は，DBC-A-1 A-5の 5 体 (Table 2-1 参照)。

DBC-B シリーズ：柱弱軸曲げ方向に HACHINOHE NS 波, 強軸曲げ方向に HACHINOHE EW 波を入力。

柱試験体は DBC-B-1〜B-2 の 2

体 (Table 2-1 参照)。

DBC-C シリーズ：柱弱軸曲げ方向に EL CENTRO

EN 波, 強軸曲げ方向に EL CE-

NTRO NS 波を入力。

柱試験体は DBC-C-1 C-4の 4

体 (Table 2-1 参照)。

各断面主軸方向に入力される地動の最大加速度を, 柱 の各断面主軸方向の降伏加速度 $\alpha_{p c x}\left(=Q_{p c x} / m, Q_{p c x}\right.$ $=2 \cdot M_{p c y} / L, M_{p c y}$ : 軸力を考慮した弱軸曲げ全塑性モ一 メント, $m$ : 質量, $L$ : 柱材長 $), \alpha_{p c y}\left(=Q_{p c y} / m, Q_{p c 3}\right.$ $=2 \cdot M_{p c x} / L, M_{p c x}$ ：軸力を考慮した強軸曲げ全塑性モ一 メント）を基準として変化させ，その組み合せにより入 力加速度の違いによる影響を検討する。Fig. 2-5に各 試験体について, 各断面主軸方向の入力波形の種頑, 最 大加速度の大きさを示す。縦軸は強軸曲げ方向の入力加 速度 $\alpha_{y}$ 之降伏加速度 $\alpha_{p c y}$ の比 $\alpha_{y} / \alpha_{p c y}$, 横軸は弱軸曲げ 方向の入力加速度 $\alpha_{x}$ 亡降伏加速度 $\alpha_{p c x}$ の比 $\alpha_{x} / \alpha_{p c x}$ を
図が弱軸曲げ方向の応答変位時刻歴, (b) 図が強軸曲 げ方向の応答変位時刻歴, (c) 図が弱軸曲げ方向の復元 力時刻歴, (d) 図が強軸曲げ方向の復元力時刻歴である。 各図中, 実線がオンライン応答解析結果で, 破線, 一点 Fig. 3-4. 5 に DBC-A-1 と DBC-A-4 の弱軸曲げ方向 ((b) 図), 水平面内での柱頭復元力の軌跡 ((c) 図), 水平面内での柱頭変位の軌跡 ((d) 図) を示す。

DBC-A-1 と DBC-A-2 では, 弱軸曲げ方向に入力す る加速度は同じであるが, 強軸曲げ方向に入力する加速 度は，DBC-A-1では，DBC-A-2の1.5 倍である。応 答変位について比較すると, DBC-A-2 では安定した応 答を示し, 地動終了時の残留変形も小さいのに対し, DBC-A-1 では，弱軸曲げ方向の変位 $u$ が正方向に大 きくシフトし, 地動終了時には大きな残留変形が生じて いる。

DBC-A-2 と DBC-A-4では，強軸曲げ方向に入力す る加速度は同じであるが，弱軸曲げ方向に入力する加速 度は，DBC-A-4では DBC-A-2 の 2 倍である。強軸曲 $v$ の最大值は， 4.36 秒での $1.66 \mathrm{~cm}$ であるのに対し， DBC-A-4 の $v$ の最大值は, 1.86 秒での $1.27 \mathrm{~cm}$ と若 干小さくなっているが, 応答波形は類似したものとなっ ている。一方，弱軸曲げ方向の応答変位 $u$ について比 較すると, DBC-A-4 の応答波形は，DBC-A-2 の応答 鎖線は次節で検討する数值解析結果である。また, 荷重-変形関係 ( $(\mathrm{a})$ 図), 強軸曲げ方向荷重-変形関係 げ方向の応答変位 $v$ について比較すると, DBC-A-2 の 

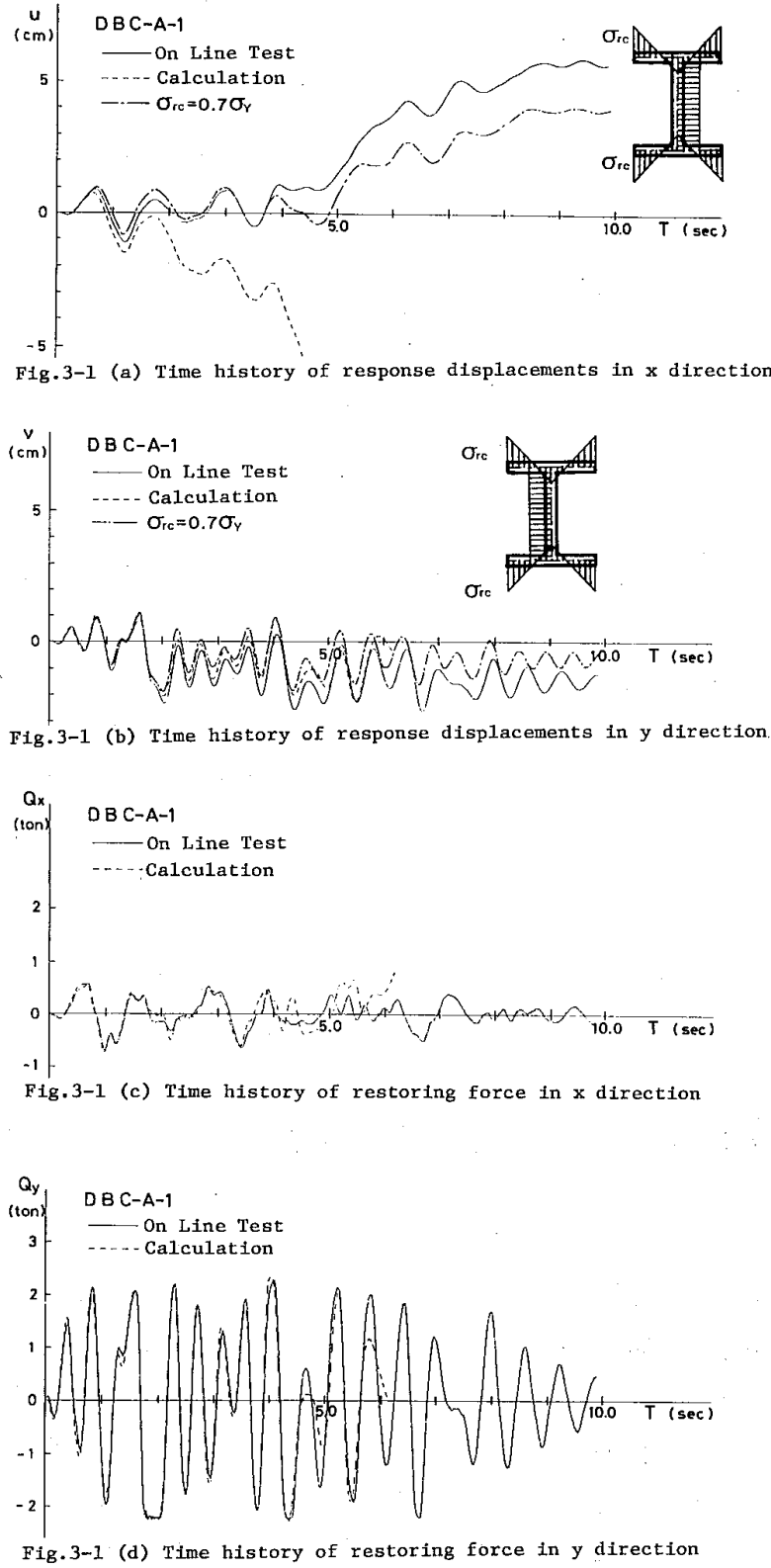

Fig. $3-1$

波形の振幅をほぼ 2 倍したものに類似しており，地動終 了時の残留変形も, DBC-A-4では, DBC-A-2の2 倍 強となっている。

DBC-A-1 の強軸曲げ方向の荷重-変形関係は，強軸 曲げ方向にのみ載荷される $\mathrm{H}$ 形鋼柱の復元力特性と類 似した曲線を示している。しかし, 弱軸曲げ方向の荷重 一変形関係では, 弱軸曲げ方向の変位が単調に増加して いる間でも, 弱軸曲げ方向の復元力は強軸曲げ方向の変 動に対応して増減するため，急な負こう配を示し複雑な 復元力特性を示している。一方, DBC-A-4では, 強軸 曲げ方向の荷重-変形関係は紡錘形を示し, 弱軸曲げ方 向の荷重-変形関係も極端な負こう配はみられず，安定 したループを示している。

以上の比較から，柱が強軸曲げ方向に大きく塑性化す ると, 弱軸曲げ方向の復元力は著しく失われ, 弱軸曲げ 方向に大きくシフトした㐫答を示すのに対し, 柱弱軸曲
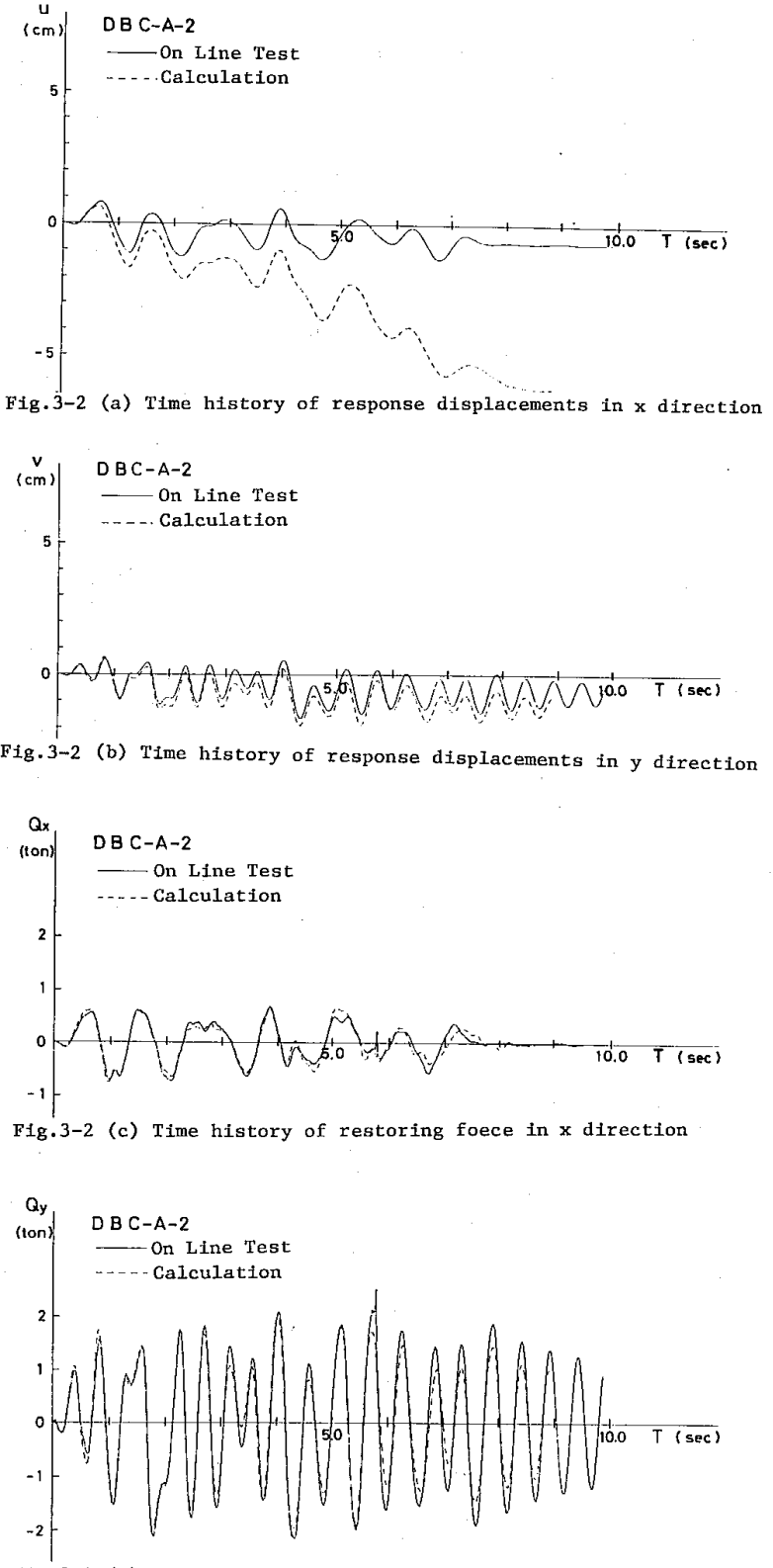

Fig.3-2 (d) Time history of restoring force in y direction

Fig. 3-2

げ方向に大きく塑性化をうけても強軸曲げ方向の応答に はあまり影響がないといえる。

オンライン応答解析を行ったすべての骨組について， 応答変位, 応答速度, 復元力の各最大值, 履歴吸収工市 ルギーを Table 3-1に示す。これらの結果から最大変位 についてまとめたものをFig. 3-6に，履歴吸収エネル ギーについてまとめたものを Fig. 3-7 に示す。各図中, ○は DBC-A シリーズ, $\square$ は DBC-B シリーズ, $\triangle$ は DBC-C シリーズの結果を示す。記号を黒く塗ったもの は，地動が終了するまでに変位が大きく発散したため実 験を途中で中止したものを，また，記号の半分を黒く塗っ たものは，最大変位が地動終了後の自由振動時に生じ， 大きな残留変形が生じたものを示す。

各断面主軸方向の最大変位 $|u|_{\text {max }},|v|_{\max }$ を $u-v$ 座 標上にプロットしたFig. 3-6に，オンライン态答実験 で用いたもの上同じ形状の模型試験体に単調ならびに繰 

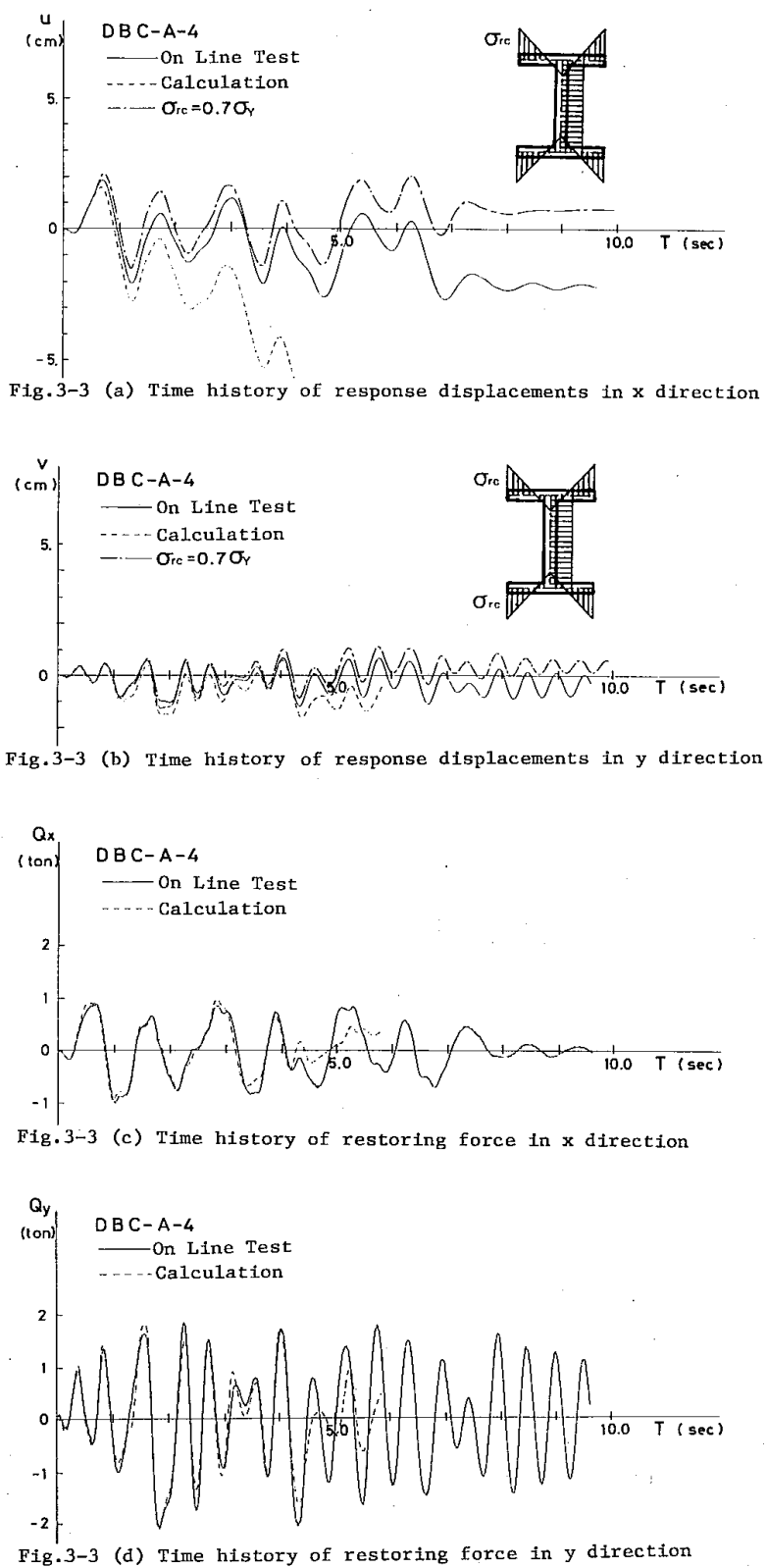

Fig. $3-3$

返し載荷したときに得られた結果をプロットする。同図 中, BBC-1 と添書きした*印は，H形断面弱軸方向に 単調載荷したとき，復元力が 0 となった際の変位量を示 し，BBC-2 - 4 と添書きした*印は，横軸を $\mathrm{H}$ 形断面 弱軸方向，たて軸を断面強軸方向として，原点を中心に それぞれの方向に繰返し載荷を行ったとき，繰返すごよ に復元力が低下し始じめる際の振幅を示している。さら に，BBC-5と添書きした点線の円は，柱材軸まわりに 円周を画く変位を与えたとき，同じく復元力が低下し始 める際の強制変位の軌跡を表している。

この図で,オンライン実験の結果 (図中, DBC は省略) についてみる亡, 強軸曲げ方向の変位 $v$ の最大值が約 $2.3 \mathrm{~cm}$ (約 $4 v_{p c}$, 図中一点鎖線) を越える場合には弱 軸曲げ方向の変位 $u$ が非常に大きくなっている。例え ば，弱軸曲げ方向の入力が同じで強軸曲げ方向の入力が 異なる場合であるA-1 とA-2, あるいは, C-2 と C-4

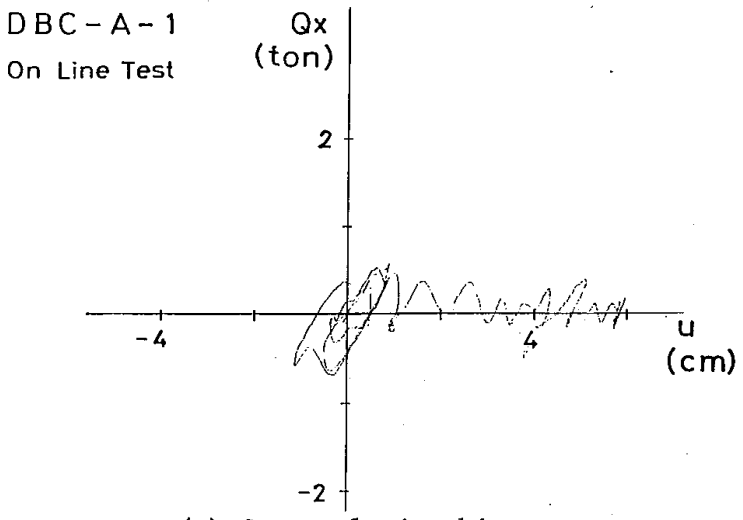

(a) $Q_{x-u}$ relationship

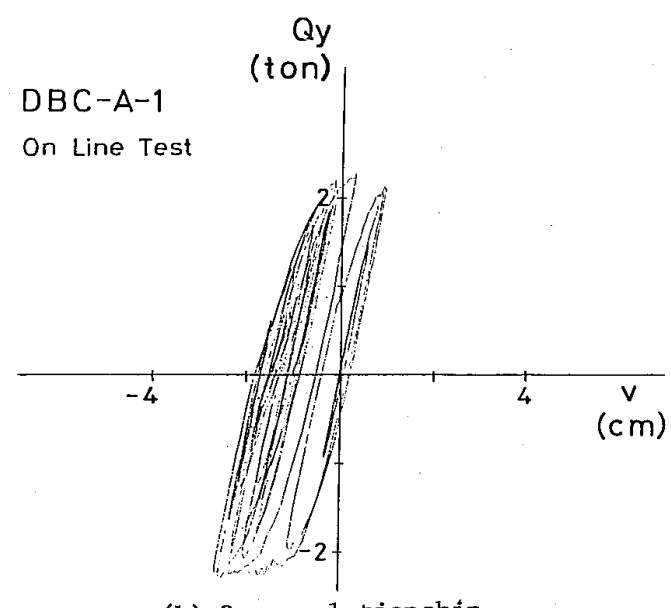

(b) $Q_{y}-\mathrm{v}$ relationship

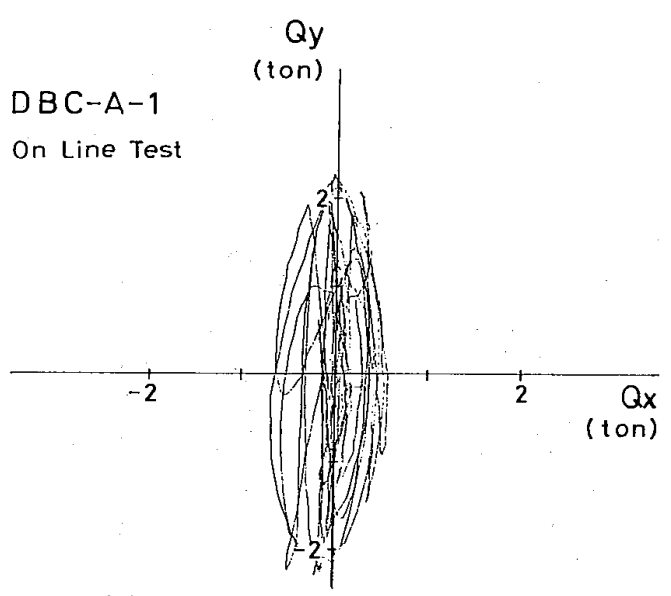

(c) Trajectory of restoring force

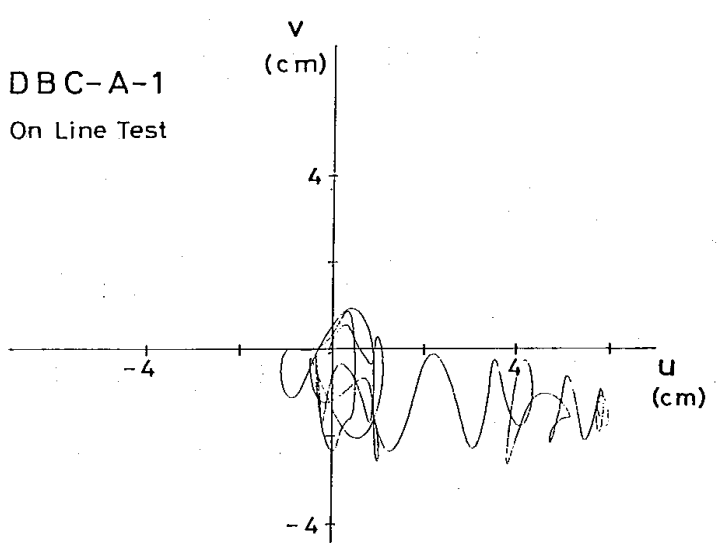

(d) Trajectory of displacement

Fig. $3-4$ 


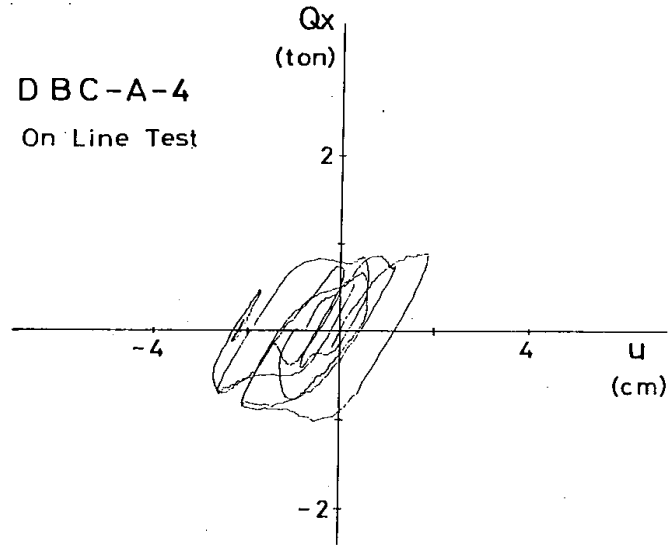

(a) Qx-u relationship

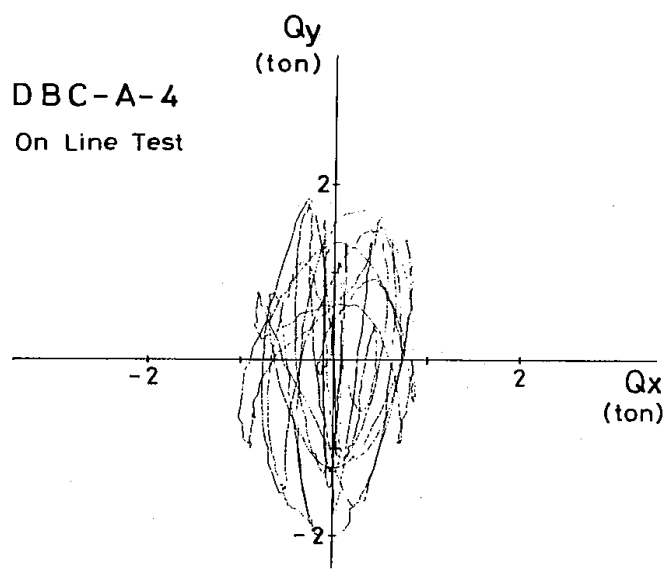

(c) Trajectory of restoring force

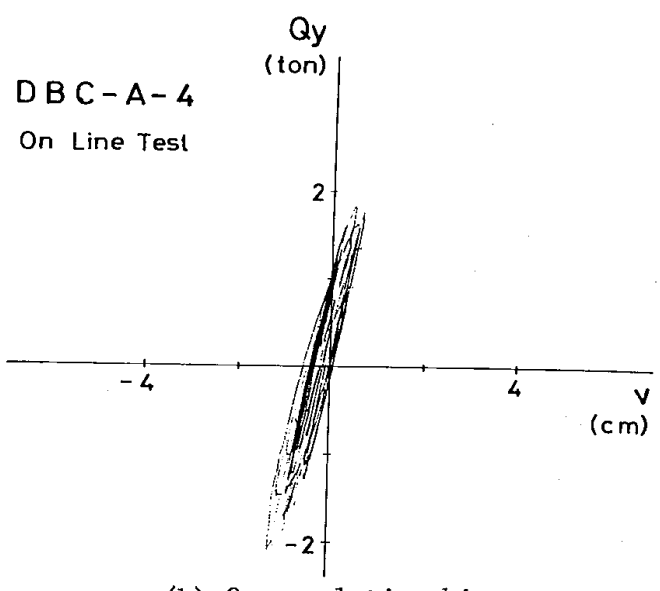

(b) $Q y-v$ relationship

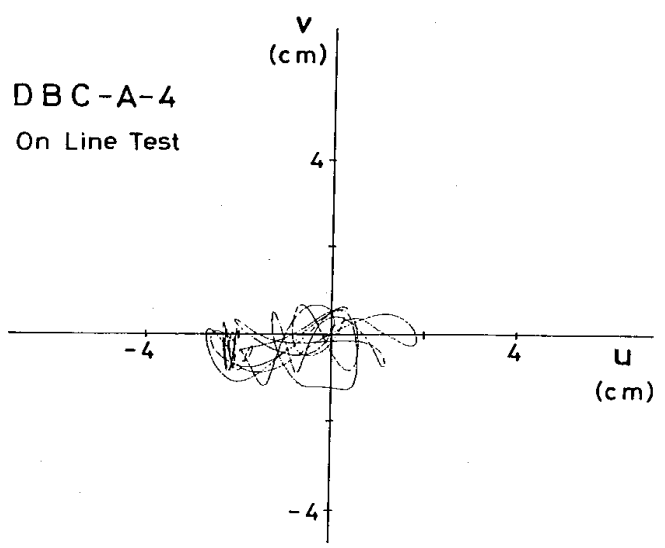

(d) Trajectory of displacement

Fig. $3-5$

Table 3-1 Results of on-line tests

\begin{tabular}{|c|c|c|c|c|c|c|c|c|c|c|c|}
\hline & $\begin{array}{c}|u|_{\max } \\
\mathrm{cm} \\
(\mathrm{sec} .)\end{array}$ & $\begin{array}{c}|v|_{\max } \\
\mathrm{cm} \\
(\mathrm{sec} .)\end{array}$ & $\begin{array}{c}\sqrt{u^{2}+v^{2}} \max \\
c m \\
\text { (sec.) }\end{array}$ & $\begin{array}{l}|\dot{u}|_{\max } \\
\mathrm{cm} / \mathrm{sec} \\
(\mathrm{sec} .)\end{array}$ & $\begin{array}{l}|\dot{v}| \max \\
\mathrm{cm} / \mathrm{sec} \\
(\mathrm{sec} .)\end{array}$ & $\begin{array}{l}\left|Q_{x}\right| \max \\
\text { ton } \\
\text { (sec.) }\end{array}$ & $\begin{array}{c}\left|Q_{y}\right|_{\max } \\
\text { ton } \\
\text { (sec.) }\end{array}$ & $\begin{array}{c}\sqrt{Q_{x}^{2}+Q_{y \max }^{2}} \\
\text { ton } \\
\text { (sec.) }\end{array}$ & $\begin{array}{c}\text { Epx } \\
\text { ton } c m \\
(\mathrm{sec} .)\end{array}$ & $\begin{array}{c}\text { Epy } \\
\text { ton cm } \\
(\mathrm{sec} .)\end{array}$ & $\begin{array}{c}E t \\
\text { ton } \mathrm{cm} \\
(\mathrm{sec} .)\end{array}$ \\
\hline$D B C-A-1$ & $\begin{array}{c}5.96 \\
(9.46)\end{array}$ & $\begin{array}{c}2.65 \\
(6.72)\end{array}$ & $\begin{array}{l}6.20 \\
(9.51)\end{array}$ & $\begin{array}{l}5.89 \\
(1.38)\end{array}$ & $\begin{array}{l}17.59 \\
(1.73)\end{array}$ & $\begin{array}{l}0.70 \\
(0.98)\end{array}$ & $\begin{array}{l}2.30 \\
(4.37)\end{array}$ & $\begin{array}{l}2.31 \\
(4.37)\end{array}$ & 2.47 & 19.01 & 21.48 \\
\hline DBC-A-2 & $\begin{array}{c}1.33 \\
(4.67)\end{array}$ & $\begin{array}{c}1.66 \\
(4.36)\end{array}$ & $\begin{array}{c}1.85 \\
(4.37)\end{array}$ & $\begin{array}{l}6.67 \\
(1.37)\end{array}$ & $\begin{array}{l}12.24 \\
(1.73)\end{array}$ & $\begin{array}{c}0.74 \\
(2.11)\end{array}$ & $\begin{array}{c}2.55 \\
(5.81)\end{array}$ & $\begin{array}{c}2.56 \\
(5.81)\end{array}$ & 2.98 & 7.25 & 10.23 \\
\hline$D B C-A-3$ & $\begin{array}{c}9.85 \\
(4.85)\end{array}$ & $\begin{array}{c}5.21 \\
(1.68)\end{array}$ & $\begin{array}{c}9.87 \\
(4.85)\end{array}$ & $\begin{array}{l}12.76 \\
(4.17)\end{array}$ & $\begin{array}{l}25.77 \\
(2.01)\end{array}$ & $\begin{array}{c}0.63 \\
(4.41)\end{array}$ & $\begin{array}{c}2.85 \\
(2.70)\end{array}$ & $\begin{array}{c}2.85 \\
(2.10)\end{array}$ & -1.18 & 48.31 & 47.13 \\
\hline $\mathrm{DBC}-\mathrm{A}-4$ & $\begin{array}{c}2.71 \\
(6.99)\end{array}$ & $\begin{array}{c}1.27 \\
(1.86)\end{array}$ & $\begin{array}{c}2.71 \\
(6.89)\end{array}$ & $\begin{array}{l}10.70 \\
(0.99)\end{array}$ & $\begin{array}{l}13.74 \\
(1.74)\end{array}$ & $\begin{array}{c}1.02 \\
(1.03)\end{array}$ & $\begin{array}{c}2.11 \\
(1.85)\end{array}$ & $\begin{array}{c}2.11 \\
(1.85)\end{array}$ & 10.65 & 7.24 & 17.89 \\
\hline $\mathrm{DBC}-\mathrm{A}-5$ & $\begin{array}{c}5.96 \\
(9.51)\end{array}$ & $\begin{array}{c}4.92 \\
(6.73)\end{array}$ & $\begin{array}{c}7.19 \\
(9.52)\end{array}$ & $\begin{array}{c}3.81 \\
(6.86)\end{array}$ & $\begin{array}{l}20.68 \\
(1.74)\end{array}$ & $\begin{array}{c}0.48 \\
(6.71)\end{array}$ & $\begin{array}{l}2.56 \\
(4.09)\end{array}$ & $\begin{array}{l}2.56 \\
(4.09)\end{array}$ & 0.15 & 31.83 & 31.98 \\
\hline$D B C-B-7$ & $\begin{array}{c}1.66 \\
(1.69)\end{array}$ & $\begin{array}{c}2.08 \\
(3.77)\end{array}$ & $\begin{array}{c}2.15 \\
(3.76)\end{array}$ & $\begin{array}{c}8.95 \\
(2.00)\end{array}$ & $\begin{array}{l}14.10 \\
(4.51)\end{array}$ & $\begin{array}{c}0.89 \\
(2.11)\end{array}$ & $\begin{array}{c}2.39 \\
(1.37)\end{array}$ & $\left(\begin{array}{l}2.39 \\
(1.37)\end{array}\right.$ & 2.56 & 13.24 & 15.80 \\
\hline $\mathrm{DBC}-\mathrm{B}-2$ & $\begin{array}{l}10.01 \\
(3.62)\end{array}$ & $\begin{array}{l}4.28 \\
(1.79)\end{array}$ & $\begin{array}{l}10.42 \\
(3.62)\end{array}$ & $\begin{array}{l}14.59 \\
(3.56)\end{array}$ & $\begin{array}{l}21.52 \\
(1.34)\end{array}$ & $\begin{array}{c}0.59 \\
(3.40)\end{array}$ & $\begin{array}{c}2.67 \\
(1.42)\end{array}$ & $\begin{array}{c}2.67 \\
(1.42)\end{array}$ & -1.02 & 28.25 & 27.23 \\
\hline$D B C-C-1$ & $\begin{array}{c}2.80 \\
(9.43)\end{array}$ & $\begin{array}{c}1.63 \\
(1.86)\end{array}$ & $\begin{array}{c}2.80 \\
(9.43)\end{array}$ & $\begin{array}{l}7.29 \\
(1.76)\end{array}$ & $\begin{array}{l}14.11 \\
(1.71)\end{array}$ & $\begin{array}{c}0.86 \\
(2.69)\end{array}$ & $\begin{array}{l}2.40 \\
(7.43)\end{array}$ & $\begin{array}{l}2.40 \\
(1.43)\end{array}$ & 2.59 & 11.68 & 14.27 \\
\hline $\mathrm{DBC}-\mathrm{C}-2$ & $\begin{array}{c}0.85 \\
(3.72)\end{array}$ & $\begin{array}{c}2.23 \\
(1.57)\end{array}$ & $\begin{array}{c}2.24 \\
(1.57)\end{array}$ & $\begin{array}{c}3.38 \\
(4.10)\end{array}$ & $\begin{array}{l}19.73 \\
(1.76)\end{array}$ & $\begin{array}{c}0.55 \\
(2.65)\end{array}$ & $\begin{array}{c}2.43 \\
(4.85)\end{array}$ & $\begin{array}{c}2.43 \\
(4.85)\end{array}$ & 0.53 & 18.94 & .12 .47 \\
\hline$D B C-C-3$ & $\begin{array}{c}7.50 \\
(71.70)\end{array}$ & $\begin{array}{c}2.71 \\
(1.61)\end{array}$ & $\begin{array}{c}7.53 \\
(11.73)\end{array}$ & $\begin{array}{l}5.30 \\
(5.41)\end{array}$ & $\begin{array}{l}28.87 \\
(1.78)\end{array}$ & $\begin{array}{c}0.50 \\
(8.68)\end{array}$ & $\begin{array}{c}2.66 \\
(4.89)\end{array}$ & $\begin{array}{c}2.66 \\
\{4.89\rangle\end{array}$ & -0.01 & 39.60 & 39.59 \\
\hline$D B C-C-4$ & $\begin{array}{l}10.06 \\
(5.17)\end{array}$ & $\begin{array}{l}2.61 \\
(1.59)\end{array}$ & $\begin{array}{l}10.07 \\
(5.62)\end{array}$ & $\begin{array}{l}11.00 \\
(5.50)\end{array}$ & $\begin{array}{l}24.47 \\
(1.78)\end{array}$ & $\begin{array}{c}0.46 \\
(2.68)\end{array}$ & $\begin{array}{c}2.46 \\
(1.86)\end{array}$ & $\begin{array}{c}2.47 \\
(1.86)\end{array}$ & -0.52 & 25.79 & 25.27 \\
\hline
\end{tabular}

Note ( ) : The time when each value above occurred. 


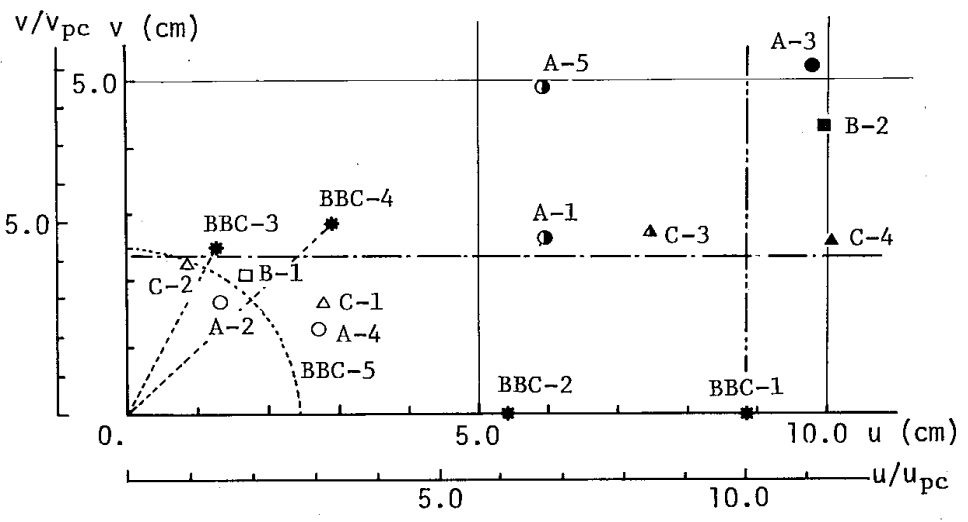

Fig. 3-6 Maximum displacement in each direction

の結果を比較してみるよ, A-2, C-2 の応答変位は比較 的安定しているのに対し，強軸曲げ方向の入力が大きく なり, 強軸曲げ方向の変位が $2.3 \mathrm{~cm}$ を超えた $\mathrm{A}-1$, C-4では弱軸曲げ方向の変位が非常に大きくなってい る。また，A-3，B-2，C-4のように，弱軸曲げ方向の 変位 $u$ が弱軸曲げ方向の単調載荷実験 (BBC-1) で復 元力が 0 となる時の変位（図中 2 点鎖線）を超える場合 には, 弱軸曲げ方向の変位は地動終了前に 1 方向に大き く発散している。

Fig. 3-7 は, 各断面主軸方向の荷重-変形曲線から求 められた履歴吸収エネルギーを $E_{p x}-E_{p y}$ 座標上に示し たものである。同図中，*印は主軸と一定の角度を持つ 方向に水平力が単調載荷される場合に復元力が 0 上なる までに各断面主軸方向で吸収されるエネルギーを，あと に示す数值解析法により求めた值である。これを図中破 線のように直線で近似し，この值を 2 倍したものを図中 に一点鎖線で示す。応答変位が大きく発散した骨組 $(\mathrm{A}-1, \mathrm{~A}-3, \mathrm{~A}-5, \mathrm{~B}-2, \mathrm{C}-3, \mathrm{C}-4)$ の $E_{p x}, E_{p y}$ は 一点鎖線を大きく上回っており，応答変位が比較的安定 していた骨組の $E_{p x}, E_{p y}$ は一点鎖線内に収まっている。 加藤・秋山は，エネルギー入力の概念に基ついた耐震設 計法を示している ${ }^{(8)}{ }^{(9)}$ 。オンライン応答実験結果から, 本報で対象としている $\mathrm{H}$ 形鋼柱の 2 方向地動下でのエ ネルギー吸収能力を次式で評価でき, 入力エネルギーを 用いて構造物の耐震性を判定することが可能であるとい える。

$$
E_{x} / E_{u x}+E_{y} / E_{u y}=1
$$

ここで $E_{x}: x$ 軸方向での入力エネルギー

$E_{y}: y$ 軸方向での入力エネルギー

$E_{u x}: x$ 軸方向での単調載荷時のエネルギー吸収 能力の 2 倍の值

$E_{u y}: y$ 軸方向での単調載荷時のエネルギー吸収 能力の 2 倍の值

\section{4. 数值解析結果との比較}

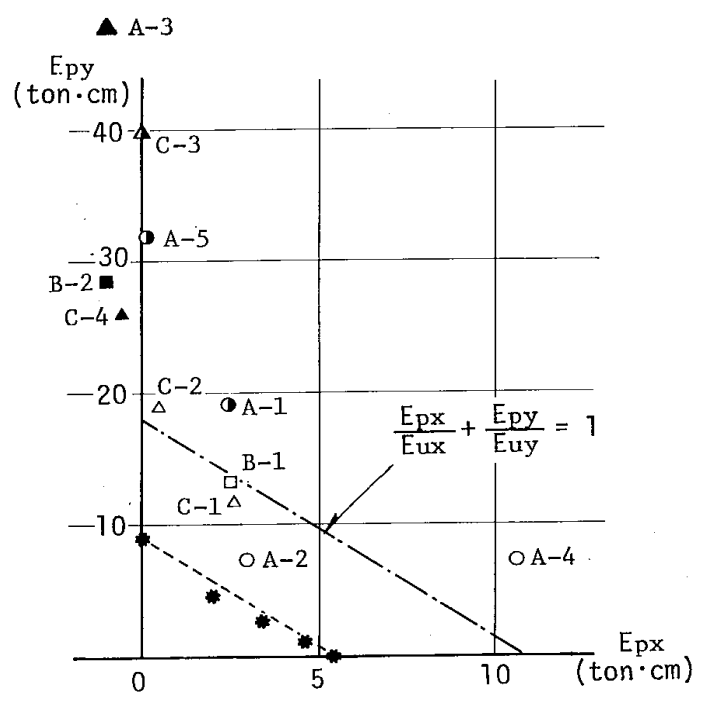

Fig. 3-7 Absorbed energy in each direction

オンライン応答実験を行った骨組と同じ骨組の応答を 数值解析法に上り求める。オンライン応答解析では, (2-1) 式の振動方程式を数值積分する際に, 復元力 $Q_{x}{ }^{i}$, $Q_{y}{ }^{i}$ を志答解析と並行して行われる実験により求めてい るが，ここでは， $Q_{x}{ }^{i}, Q_{y}{ }^{i}$ を部材の数值解析により求 める。解析上の仮定は次のとおりである。

1) 応力, ひずみの成分は, 断面垂直成分のみを考え, せん断応力度の影響は無視する。

2）据れ変形，㨝りモーメントは考虑しない。部材の “変形に及ぼすせん断力の影響も無視する。

3）軸力は柱軸長に沿って一定である。

4）微小変形，增分理論に基づくものとする。

5）部材の曲率は，たわみの材軸方向の变数に関する 2 次微分によってあらわされる。

6) 断面の平面は保持され, 断面形は変形後も元の形 を保つ。

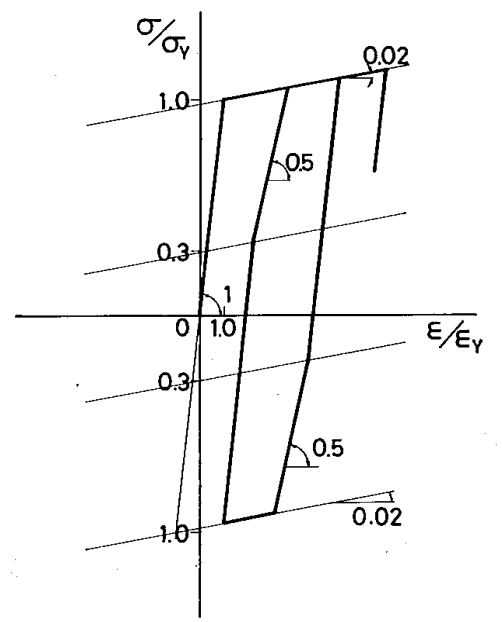

Fig. 4-1 Tri-linear type stress-strain model used in the numerical analysis 
7）曲げ捩れ座屈，局部座屈は考慮しない。

8）鋼素材の応力ーひずみ関係は，Fig. 4-1に示す Tri-linear 型とする。

解析方法は概略次の通りである。オンライン応答実験 と異なるところは，振動方程式（2-1-a，b）において $t=i \cdot \Delta t$ 時の復元力 $Q_{x}{ }^{i}, Q_{y}{ }^{i}$ を計算によって求めるこ とである。これを計算するのに，まず，柱部材を材軸に 平行な線素に分割し，上に述べた仮定を用いて， $t=i$ ・ $\Delta t$ 時の各線素の伸縮を計算する。応力ーひずみ関係は あらかじめ与えられているから，この伸縮量に対応する 各線素の応力度が計算できる。したがって，柱のビの断 面における曲げモーメントも計算できるからこの曲げ モーメントの分布から, 式 (2-1-a, b) で定義する復 元力 $Q_{x}{ }^{i}, Q_{y}{ }^{i}$ も計算できる。復元力がわかれば, 式 (2-1-a, b) を解くことは可能で, 応答量を知ること ができる。この計算においても，オンライン応答実験同 様, step by step の計算法を採用する。以下の解析例で は, 時間刻み $\Delta t$ を 0.01 秒とし, 振動方程式の積分は 線形加速度法を用いている。

この計算方法を, オンライン応答実験で用いたもの之 同じ $\mathrm{H}$ 鋼柱に静的な繰返し載荷を与えたときの挙動の 解析に応用した例は文献（10）に示している。

解析結果として応答変位および復元力の時刻歴を Fig. 3-1〜3 中に破線で示す。応答変位の時刻歴につい て各図中の実線で示されるオンライン実験結果と比較す ると, 柱強軸曲げ方向の変位は, 数值解析により, 上く 再現できているといえる。しかし, 弱軸曲げ方向の応答 変位は, 発散する方向が逆になるなよ゙, その挙動を定量 的に予測するのが困難な場合がある。オンライン応答実 験で用いた $\mathrm{H}$ 形鋼柱試験体は，溶接組立で製作されて おり, 焼鈍等の後処理を行っていないため残留応力の影 響が考えられる。参考のため DBC-A-1，DBC-A-4 に ついて, 残留応力を仮定した数值解析を行った。結果と して応答変位の時刻歴を Fig. 3-1，3 中に一点鎖線で示 すが，実験結果上の対応は，はるかによくなっている。 なお, 残留応力の分布形は, Fig. 3-1, 3 中に示すもの を仮定している。

\section{5. 結語}

本報では，電算機一試験機オンラインシステムを利用 して, 定軸力下で水平 2 方向の地震入力をうける $\mathrm{H}$ 形 鋼柱の応答性状，崩壊過程を調べた。オンライン応答実 験に使用した $\mathrm{H}$ 形鋼柱試験体は，溶接組立てにより製 作した $\mathrm{H}_{\mathrm{B}}-70 \times 70 \times 6 \times 6, B / t_{f}=12.0, \lambda_{x}=32, \lambda_{y}=53$ で,

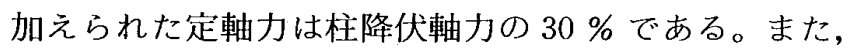
オンライン応答実験結果と 4. に示した数値解析法を用 いた応答結果との比較検討を行った。結果を次にまとめ る。

1） 2 方向入力をうける $\mathrm{H}$ 形鋼柱の柱弱軸曲げ方向
の復元力特性は, 柱強軸曲げ方向の挙動の影響を強 くうけ非常に複雑なものとなる。復元力特性のモデ ル化を一切行わずに現実の復元力に基づいて応答解 析をすすめる電算機一試験機オンライン応答解析は, このような構造物の応答解析に有効な方法である。

2）強軸曲げ方向の最大変位が特定の值（約 $4 \cdot v_{p c}$ ) を超えると弱軸曲げ方向の変位が大きく 1 方向にシ フトし大きな残留変形が生じた。また, 弱軸曲げ方 向の変位が, 弱軸曲げ方向にのみ単調載荷される場 合に復元力が 0 となる変位を超える亡, 応答変位は 急激に大きくなり，地動終了前に大きく発散した。

3）本報で対象よした $\mathrm{H}$ 形鋼柱の場合, 各断面主軸 方向にのみ単調載荷されるときに復元力が 0 となる までに吸収しうるエネルギーの 2 倍の值を用いて， (3-4) 式から 2 方向載荷時のエネルギ一吸収能力が 評価でき，このような方法により 2 方向地動をうけ る構造物の耐震性を判定できることが確められた。

4）捩れ変形を無視し, 鋼素材の応力ーひずみ関係と してTri-linear 型モデルを仮定するなど簡略化した 数值解析法により，柱強軸曲げ方向の応答変位はよ く再現できるが, 弱軸曲げ方向の応答変位は定量的 に予測することが困難な場合がある。

\section{謝辞}

本研究は, 昭和 53 年度, 54 年度の文部省科学研究費 補助金「2 方向繰返し曲げをうける鋼柱の弾塑性挙動之 耐力」(代表者 由中 尚) No. 355239 によるもので ある。実験に当たっては，東京大学生産技術研究所の大 并謙一助手, 嶋脇与助, 近藤日出夫各技官, 山口一夫氏 (現 上越教育大技官)，山口哲也氏(現川崎製鉄）の協力を 得た。ここに記して謝意を表する。

\section{参考文献}

（1）藤本盛久, 緑川光正：“鋼構造立体骨組の動的弾塑性応 答に関する研究”（その1）日本建築学会論文報告集, 第 282 号, 昭和 54 年 8 月, (その 2 ) 日本建築学会論 文報告集, 第 298 号, 昭和 55 年 12 月

（2）松井干秋, 森野捷輔, 内田保博: “水平 2 方向外力を受 ける $\mathrm{H}$ 形鋼柱の弾塑性応答性状” 日本建築学会大会学 術講演梗概集, 昭和 53 年 9 月, (その 2 ), 同, 昭和 54 年 9 月, (その 3 ), 同, 昭和 55 年 9 月

(3) N.C. Nigam: "Yielding in Framed Structures under Dynamic Loads” Proc. of A.S. C.E., Vol. 96, No. EM 5, Oct, 1970

(4) T. Kobori, R. Minai, T. Fujiwara : "Earthquake Responsc of Frame Structures Composed of Inelastic Members" Proc. of 5 th WCEE, 1973

（5）高梨晃一, 宇田川邦明, 関松太郎, 岡田恒男, 田中 尚：“電算機一試験機オンラインシステムによる構造物 の非線形地震応答解析一 (その1. システムの内容)” 日本建築学会論文報告集, 第 229 号, 昭和 50 年 3 月

(6) 高梨晃一, 宇田川邦明, 田中 尚: “電算機-試験機才 ンラインシステムによる構造物の非線形地震応答解析 
(その 3. 2 層鉄骨フレームの解析例)" 日本建築学会 論文報告集，第 288 号，昭和 55 年 2 月

（7）岡田恒男，関松太郎，朴 永周，岡田健良：“2方向地 震入力に対する鉄筋コンクリート建物の応答”（その 1 ), (その 2$),(そ の 3)$, 日本建築学会大会学術講演 梗概集，昭和 52 年 10 月

（8）加藤 勉, 秋山 宏：“強震による構造物へのエネル ギー入力と構造物の損傷”日本建築学会論文報告集,
第 235 号, 昭和 50 年九月

（9）加藤 勉, 秋山 宏：“鋼構造剛接骨組の耐震極限設計” 日本建築学会論文報告集, 第 237 号, 昭和 50 年 11 月

(10) 高梨晃一, 谷口英武, 田中 尚: “定軸圧下で, 任意方 向の繰返し水平力を受ける $\mathrm{H}$ 形鋼柱の弾塑性挙動（2 方向水平地動を受ける $\mathrm{H}$ 形鋼柱の弾塑性応答性状 ( I ))”日本建築学会論文報告集, 第 323 号, 昭和 58 年 1 月

UDC : 624. 078. $014.5: 624.042 .7: 620.1: 681.3$

Trans. of A. I.J.

暑本建築学会論文報告集

\title{
EARTHQUAKE RESPONSE ANALYSIS BY COMPUTER- ACTUATOR ON-LINE SYSTEM
}

\author{
Inelastic Response of $\mathrm{H}$-shaped Columns to Bi-directional \\ Horizontal Earthquake Ground Motions(II)
}

\section{By Dr. HIDETAKE TANIGUCHI, Dr.KOICHI TAKANASHI and Dr.HISASHI TANAKA, Members of A. I. J.}

\section{Introduction}

Many researches have been reported on the response of structures to bi-directional earthquake ground motions by the numerical analysis methods, where some analytical models were assumed. However, enough informations as to the appropriateness of these analytical models have not been obtained. The authors have developed a non-linear earthquake respones analysis method by the computer-load test apparatus hybrid system, so-called "on-line system" (5)(7). In the analysis by this system, the responses are computed by using the real restoring forces obtained from the computer-controlled column tests. Main objectives of this paper are 1) to investigate the response behavior of $\mathrm{H}$-shaped steel columns to bi-directional earthquake motions by the computer-actuator on-line analysis method and 2) to examine the appropriateness of the numerical analysis method.

\section{Computer-Actuator On-line Analysis}

2-1 Analytical model and procedure of analysis

The analysis of a single column is considered enough to predict the response behavior of a square single story building model which comprises a rigid floor and identical H-shaped steel columns. Therefore, the analytical model can be reduced to a lumped mass system as shown in Fig. 2-1. In the case where the rotation about the column axis is neglected, the equations of motions at $i$-th step can be expressed as Eq. (2-1). In these equations, the response accelerations, $\ddot{u}^{i}$ and $\ddot{v}^{i}$, can be expressed approximately as Eq. (2-2). In the on-line analysis the response displacements, $u^{i+1}$ and $v^{i+1}$, at next step can be calculated from Eq. (2-1) and Eq. (2-2) by use of $Q_{x}{ }^{i}$ and $Q_{y}{ }^{i}$ measured by the load test on the column specimen which is controlled by the computer as shown in Fig. 2-2.

\section{2-2 On-line tests}

To measure the restoring force characteristics of the bi-axial bending columns, the load tests were carried out on the welded built-up $\mathrm{H}$-shaped steel column specimens, $\mathrm{H}-70 \times 70 \times 6 \times 6$.

2-3 Ground acceleration records and frame properties

The variables considered were the ground motion characteristics (EW and NS components of 1968 HACHINOHE, and EW and NS components of 1940 EL CENTRO) and the scaled intensities were decided on 
the basis of the yield acceleration $\alpha_{p c}\left(\alpha_{p c}=M_{p c} /(m L / 2), M_{p c}=\right.$ full plastic moment under thrust $)$. The fundamental elastic period with respect to the strong axis bending motion of the analyzed frame is fixed 0.5 second. The properties of analyzed frames and input ground accelerations are summarized in Table 2-2.

\section{Results of on-line analysis}

Some results of the on-line analysis are shown in Fig. 3-1 to 5. The time history of the response displacements in the weak axis bending plane, those in the strong axis bending plane, the restoring forces in the weak axis bending plane, those in the strong axis bending plane are shown in Fig. 3-1, 2, 3, respectively, in the analyses on $\mathrm{DBC}-\mathrm{A}-1, \mathrm{~A}-2$ and $\mathrm{A}-4$.

The restoring force-displacement relationship in the weak axis bending plane, that in the strong axis bending plane, the trace of the response displacements and the trace of the restoring forces are shown for DBC-A-1 and A-4 in Fig. 3-4 and 5, respectively. The results for all frames analyzed are summarized in Table 3-1.

The maximum response displacement in each direction and the absorbed energy in each direction are summarized in Fig. 3-6 and 7 respectively. In Fig. 3-6, a chain lines show the deformation capacity in the strong and weak axis bending directions of the bi-axial bending $\mathrm{H}$-shaped steel columns. In Fig. 3-7, a chain line shows the absorbed energy capacity of the bi-axial bending $\mathrm{H}$-ahaped steel columns.

\section{Comparison with numerical analysis results}

The numerical analysis were conducted on the same columns as used in the on-line analysis.

The results of DBC-A-1, A-2 and A-4 are represented by dashed lines in Fig. 3-1 to 3 for comparison. The numerical analysis considering the residual stress were also conducted, the results of which are shown by a chain line in Fig. 3-1 to 3 also.

\section{Conclusions}

The non-linear response behavior of $\mathrm{H}$-shaped steel columns to bi-directional earthquake motions was investigated by the computer-actuator on-line analysis method. The restoring force characteristics in the weak axis bending plane result in very complicated curve. The large drift in the weak axis bending plane occured in the case that the response displacement in the strong axis bending plane became larger than the level, say, $4-v_{p c}$ The absorbed energy capacity of H-shaped steel columns under bi-axial bending can be evaluated by Eq. (3-1). A simple numerical analysis method for beam-columns under biaxial bendings is available for rough estimation of response of H-shaped steel columns to two-directional earthquake motions. 